\title{
Physicochemical, Mineral and Sensory Characteristics of Cashew Nut Milk
}

\author{
Emelike Nkechi Juliet Tamuno*, Akusu Ohwesiri Monday \\ Department of Food Science and Technology, Rivers State University, Nkpolu Oroworukwo, Port Harcourt, Rivers State, Nigeria
}

Email address:

njtemelike.nkechi@yahoo.com (E. N. J. Tamuno)

${ }^{*}$ Corresponding author

\section{To cite this article:}

Emelike Nkechi Juliet Tamuno, Akusu Ohwesiri Monday. Physicochemical, Mineral and Sensory Characteristics of Cashew Nut Milk. International Journal of Food Science and Biotechnology. Vol. 4, No. 1, 2019, pp. 1-6. doi: 10.11648/j.ijfsb.20190401.11

Received: January 11, 2019; Accepted: February 18, 2019; Published: March 15, 2019

\begin{abstract}
Physicochemical and sensory characteristics of cashew nut milk were investigated. Cashew nut milk was produced and added with sugar and vanilla flavour at different proportions. The proximate and mineral composition of the plain cashew nut milk was analysed, as well as the physicochemical and sensory characteristics of the cashew nut milk containing sugar and vanilla flavour were analysed. The results revealed a reasonable amount of protein $(5.00 \%)$, fat $(5.49 \%)$, ash $(0.90 \%)$ and carbohydrate $(5.95 \%)$ in the plain cashew nut milk with high moisture content of $82.66 \%$. Physicochemical analysis showed that the cashew kernel milk with only sugar content had higher sugar value of $14 \%$ and specific gravity of $1.06 \mathrm{~g} / \mathrm{cm}^{3} \mathrm{but} l \mathrm{low}$ in $\mathrm{pH}$ (5.60) than other samples. Viscosity was higher for the plain milk $(2.80 \mathrm{Cp})$ with low acidity $(0.04 \%)$ than other samples. The plain cashew nut milk sample contained appreciable quantities of calcium $(4.75 \mathrm{mg} / 100 \mathrm{~g})$, potassium $(7.15 \mathrm{mg} / 100 \mathrm{~g})$, iron $(3.00 \mathrm{mg} / 100 \mathrm{~g})$, magnesium $(2.00 \mathrm{mg} / 100 \mathrm{~g})$ and phosphorus $(2.00 \mathrm{mg} / 100 \mathrm{~g})$. The sensory analysis showed that the cashew kernel milk with only sugar incorporation was most acceptable for all sensory parameters and this is in correspondence to the total sugar content as this sample had more sugar as compared to others. The addition of sugar and vanilla flavour significantly ( $\mathrm{p}<0.05$ ) affected the $\mathrm{pH}$, titratable acidity and sensory properties of cashew kernel milk. The incorporation of sweeteners in cashew kernel milk should be encouraged and the milk utilized by health conscious individuals so as to stabilize the cost of dairy milk.
\end{abstract}

Keywords: Cashew Nut Milk, Sweeteners, Plant Milk, Health Consciousness, Physicochemical, Sensory

\section{Introduction}

Emphasizes on healthy nutrition and healthy living has necessitated the consumption of functional foods, low fat and low cholesterol diets. It has also led to an increasing demand of plant origin milk products and decreasing demand of animal origin milk. This is due to the occurrence of health related problems associated with the consumption of animal milk and its products such as lactose intolerance, milk allergy, increased cholesterol, constipation, flatulence as well as high cost of diary milk. This decrease in consumption of animal milk has stimulated several researchers to develop substitutes from different seeds and nuts. This has led to the development of milk from legumes, oil seeds and nuts; such as Coconut/natural milk blend [1], Corn/soy milk blends [2], tiger nut/bambara nut/coconut milk blends [3], Soy/peanut chocolate flavoured beverage [4] and flavoured vegetable milk drink from tiger nut and coconut milk blends [5]. Milk from plant origin are known to be highly nutritious, beneficial to the health and has relatively low price [6]. They can be used to combat coronary heart and cardiovascular diseases as well as malnutrition in under developed countries [7].

Cashew (Anacardium occidentale L.) is a tree belonging to the family Anacardiaceae and grown extensively in India, Brazil, East Africa and Vietnam [8]. The tree grows well on poor soil under various climatic conditions. Cashew kernel has not fully been utilized in Nigeria while its production is on the increasing side yearly. FAO [9] reported that in the last few years, the production of cashew nuts/kernels in Nigeria has increased from 30,000 tons in 1990 to 176,000 tons in 2000. About $60 \%$ of cashew kernels are consumed in form of snacks, few percentage out of $40 \%$ are used in the manufacture of confectioneries [10] while the remaining are wasted as a result of lack of proper storage or processing technique. Cashew kernel is a rich plant source of fat $(47.1 \%)$, ash $(4.7 \%)$, fibre $(1.2 \%)$ and protein $(19.8 \%)$ as reported by Emelike et al. [11]. 
The cashew kernel contains an average of $48 \%$ oil which are oleic $(73.73 \%)$, linoleic $(13.60 \%)$ and stearic $(10.20 \%)$ acids in the ratio of $1: 2: 1$. The ratio of these fatty acids present can be used to lower blood serum cholesterol [12]. The kernels can be eaten in the roasted form, raw, fried and sometimes salted or sweetened with sugar, garlic, ginger and honey. It can be processed into flour for the fortification of snack products [13] Many researchers are putting efforts to the study of cashew nut/kernel to hence its utilisation in Nigeria. Physicochemical characteristics of cashew nut flour [14], protein concentrates and isolates produced from cashew nut [15], quality characteristics of cashew by-products [16] among others has been reported.

High demand for plant based milk and its products by health conscious consumers has prompted researchers into carrying out studies on milk substitutes from cheap available various plant sources. Plant-based milk from adenanthera pavonina seed [17], vegetable milk from Treculia africana (Decne) seeds [18] and vegetable milk from almond kernels [19] were all studied for this purpose. The development of milk substitute extracted from Nigerian abundant cashew kernel could also be a promising one as an alternative source of acceptable nutritious plant milk. Hence, the aim of this study was to produce cashew kernel milk, analyse the proximate and mineral contents of the plain milk, as well as physicochemical and sensory characteristics of the milk product with added levels of sugar and vanilla flavour in comparison with the plain sample.

\section{Materials and Method}

\subsection{Sample Collection and Treatment}

Eight kilograms of mature cashew (Anacardium occidentale L.) nut were collected from Kogi State and transferred to the Laboratory of Food Science Technology Department, Rivers State University, Port Harcourt, Nigeria for processing. The collected samples were cleaned to remove debris and sun dried to eliminate deterioration during storage. The nuts were conditioned by mild spraying with water to increase flexibility as well as prevent scorching during processing. All reagents used were of analytical grades (BDH chemicals U. K) and were obtained from the same Laboratory.

\subsection{Processing of Cashew Nuts}

Cashew nuts were processed using oil immersion method as described by Emelike et al. [11]. The conditioned nuts were placed in a metal basket and immersed in a pot of hot vegetable oil (King's oil) for about $1 \mathrm{~min}$ to absorbed the cashew nut shell liquid (CNSL). The nuts were stirred at 10 sec intervals to prevent scorching while in the hot vegetable oil. The cashew nuts were then poured out after $1 \mathrm{~min}$ and allowed to cool for about $1 \mathrm{hr}$. The nuts were cracked using a wooden mallet to extract the kernels. The extracted kernels were further roasted in an open iron pan with constant stirring for $20 \mathrm{~min}$.

\subsection{Production of Cashew Kernel Milk}

Extraction of milk from cashew kernel was carried out as described by Adedokun et al. [3] with some modifications. Cashew kernel was divided into three portions of $450 \mathrm{~g}$ each and then soaked in $250 \mathrm{ml}$ of portable water for $6 \mathrm{hr}$. After soaking, the water was drained and each portion of the soaked kernel blended (using Philips HR2000 blender) into slurry at the ratio of kernel to water of 1:6. The slurry was filtered using a clean piece of white triple-folded muslin cloth to separate the milk. The milk obtained was divided into four batches of $100 \mathrm{ml}$ each. The first batch was used plain, the second batch was added with $10 \mathrm{~g}$ of vanilla flavour and $5 \mathrm{~g}$ of sugar, third batch was added with $15 \mathrm{ml}$ of vanilla flavour while fourth batch was added with only $15 \mathrm{~g}$ of sugar. All the milk samples were homogenized manually, filled in heat bottles and pasteurized at $82^{\circ} \mathrm{C}$ for $10 \mathrm{~min}$ in a water bath. The cashew kernel milk beverages were then cooled to room temperature at $28 \pm 2{ }^{\circ} \mathrm{C}$ under running tap water and then refrigerated to prevent the growth of microbes until used for analysis. The produced cashew kernel milk samples are presented in figure 1.

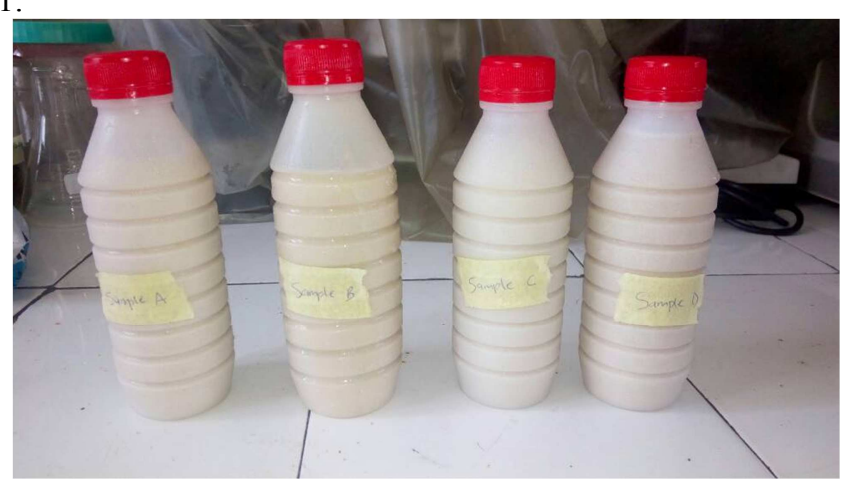

Figure 1. Cashew Kernel Milk.

\subsection{Chemical Analysis}

Chemical analysis of the cashew kernel milk samples was carried out to determine the moisture, ash, fat and protein contents of the milk product using the official method of analysis described by the Association of Official Analytical Chemists [20] while carbohydrate was determined by difference.

\subsection{Physical Analysis}

\subsubsection{Milk Viscosity}

One hundred millimeter of each sample was measured into a beaker, viscometer was determined with the aid of a Rotary Digital Viscometer (NDJ-85) by using spindle number 2 at 12 rpm. The content of the beaker was introduced onto the rotating spindle and values displayed on the LCD screen in $\mathrm{Cp}$. The value displayed was taken as the viscosity of the sample [20].

\subsubsection{Total Titratable Acidity}

Ten millilitres of the milk samples were weighed into a beaker. Two drops of phenolphtalein indicator were added to each sample and were titrated against $0.1 \mathrm{~N}$ of sodium 
hydroxide $(\mathrm{NaOH})$. The appearance of a change in colour (pink) indicated the end point of titration. The titratable expressed as percentage (\%) of malic acid (0.067) [20].

\subsubsection{Specific Gravity}

The specific gravity of the cashew kernel milk was determined as described by AOAC [20]. A picnometer bottle was washed and dried in an oven at $105^{\circ} \mathrm{C}$ for $15 \mathrm{~min}$, cooled and then weighed as $\mathrm{W}_{1}$. The picnometer bottle was filled with distilled water to the brim and the bottle stoppered. The body of the bottle was wiped with a tissue to remove excess water and then the bottle containing distilled water weighed as $\mathrm{W}_{2}$. After weighing, the distilled water was poured out. The density bottle was then filled with the sample to the brim and stoppered. The body of the bottle was again wiped with a tissue and the bottle containing sample weighed as $\mathrm{W}_{3}$. Specific gravity was obtained using the following formula;

$$
\text { Specific gravity }=\frac{\text { Density of milk }}{\text { Density of water }}
$$

\subsection{4. pH of Cashew Kernel Milk}

The $\mathrm{pH}$ of the cashew kernel milk beverages were determined using Thomas Scientific pH meter (TS 625, USA). Ten millilitres of the samples were measured into a $50 \mathrm{ml}$ beaker and the electrode of the $\mathrm{pH}$ meter was immersed in the sample and then the reading on the $\mathrm{pH}$ meter was taken.

\subsubsection{Total Sugar Content ('brix)}

Sugar content was determined using a hand held refractometer ATAGO $\left(0-32^{\circ}\right.$ Brix $)$ at $20^{\circ} \mathrm{C}$. A drop of the sample was placed on the plate of the instrument and then covered to disperse, the dispersed sample was viewed with the help of a light source to obtain a reading. The value derived was taken as the amount of sugar in the sample and recorded in degree brix [20].

\subsection{Mineral Analysis}

Mineral analysis of cashew kernel milk was carried out according to AOAC [20] method using the Atomic Spectrophotometer (AAS). Minerals that were determined included Potassium, Calcium, Iron, Magnesium and Phosphorus contents.

\subsection{Sensory Analysis}

The sensory attributes of the cashew kernel milk beverage samples were obtained by using simple hedonic test scale as described by Iwe [21]. This was carried out using a 20 member panel comprising of students from the Department of Food Science and Technology, Rivers State University, who are familiar with the sensory attributes of milk and neither sick nor allergic to milk. The panelist was asked to score each attribute on a 5-point hedonic scale where 1 and 5 represent dislike extremely and like extremely, respectively. The sensory parameters evaluated were colour, appearance, taste, mouth feel, flavour, thickness and overall acceptability.

\subsection{Statistical Analysis}

The analysis was carried out in duplicate and data obtained were subjected to Analysis of Variance (ANOVA) using Statistical Package for Social Science (SPSS, Inc. Chicago) Version 20.0, year 2011. Significant difference between samples was tested using the Least Significant Difference test (LSD).

\section{Results and Discussion}

\subsection{Proximate Composition of Plain Cashew Nut milk}

The proximate composition of plain milk produced from cashew nut is presented in Table 1 . The moisture content of the milk beverage was $82.66 \%$ which was higher than the moisture content of tiger nut beverage $(79.29 \%)$ and bambara groundnut (79.24\%) as reported by Adedokun et al. [3]. The difference in the moisture content of the milk beverage could be due to the amount of water used in the extraction process. In addition, the high moisture content is an indication that preservation of the milk beverage is required through cold storage. Ash value is used to measure the level of mineral content in a food commodity. Ash content of the produced milk beverage was $0.9 \%$ and it's higher when compared with the findings of Rehman et al. [22] for soymilk $(0.58 \%)$ and Alyaquobi et al. [23] for fresh coconut milk (0.71 - 0.90\%). Fat content of the produced cashew nut milk is $5.49 \%$ which is high compareto that of tiger and bambara nut milks with the values of $3.12 \%$ and $2.04 \%$, respectively reported by Adedokun et al. [3]. Rehman et al. [22] also reported 2.28\% for soy milk and $3.80 \%$ for cow milk. Emelike et al. [11] reported cashew nut to be rich in fat $(47.1 \%)$. The level of fat in the milk was higher than the minimum recommended $3 \%$ level by the Codex Alimentarius Standard [24]. Cashew nut milk contains $5.0 \%$ protein and its relatively high than the protein content of soy-peanut chocolate flavoured beverage, tiger nut milk and coconut milk with the values of $3.37 \%$ and $2.06-3.50 \%[23,25,26]$. Cashew nut milk had carbohydrate content of $5.95 \%$. The percentage carbohydrate obtained was less than that of bambara nut and tiger nut $(7.48 \%$ and $11.82 \%$, respectively) as reported by Adedokun et al. [3] and higher than that of soy milk with the value of $4.78 \%$ [27].

Table 1. Proximate Composition of Plain Cashew Nut Milk.

\begin{tabular}{lc}
\hline Parameter & Composition (\%) \\
\hline Moisture & $82.66 \pm 0.42$ \\
Ash & $0.90 \pm 0.28$ \\
Protein & $5.00 \pm 0.57$ \\
Fat & $5.49 \pm 0.79$ \\
Carbohydrate & $5.95 \pm 0.37$ \\
\hline
\end{tabular}

Results are mean values of duplicate determinations.

\subsection{Mineral Composition of Plain Cashew Nut Milk}

The analysis showed that plain cashew nut milk had calcium content of $4.75 \mathrm{mg} / 100 \mathrm{~g}$, potassium $7.15 \mathrm{mg} / 100 \mathrm{~g}$, iron $3.0 \mathrm{mg} / 100 \mathrm{~g}$ while magnesium and phosphorus had 
similar values $2.0 \mathrm{mg} / 100 \mathrm{~g}$ as presented in Table 2. Value obtained for iron was higher than that of soy milk and lower than almond milk with the values of $0.58 \mathrm{mg} / 100 \mathrm{~g}$ and $13.10 \mathrm{mg} / 100 \mathrm{~g}$, respectively [28]. These authors equally reported lower calcium values for soy milk $(3.25 \mathrm{mg} / 100 \mathrm{~g})$ and almond milk $(2.15 \mathrm{mg} / 100 \mathrm{~g})$. The observed level is expected as cashew nut have been reported to be a rich source of minerals [11]. The level of calcium and iron in this study for cashew nut milk suggests that its consumption will contribute immensely to the reduction of mineral deficiencies in developing countries.

Table 2. Mineral Composition of Plain Cashew Nut Milk.

\begin{tabular}{ll}
\hline Parameter & Composition $\mathbf{( m g / 1 0 0 g )}$ \\
\hline Calcium & 4.75 \\
Potassium & 7.15 \\
Iron & 3.00 \\
Magnesium & 2.00 \\
Phosphorus & 2.00 \\
\hline
\end{tabular}

Results are mean values of duplicate determinations.

\subsection{Physicochemical Properties of Cashew Nut Milk Samples}

The physicochemical properties of plain milk, sugar and vanilla flavoured milk products are shown in Table 3. Total titratable acidity of the cashew nut milk ranged from 0.04 $0.12 \%$ with the plain milk sample having the lowest acidity and milk sample containing both sugar and vanilla flavour had the highest value. There was a significant $(p>0.05)$ difference in the acidity of the milk samples and this could be attributed to the addition of sugar and vanilla flavour to the cashew nut milk products. The acidity of the produced cashew nut milk was lower than that of soy milk and tiger nut milk with the values of $0.24 \%$ and $0.15 \%[22,29]$.

The specific gravity of the milk samples were not significantly $(\mathrm{p}<0.05)$ different with each other with values that ranged from $1.03 \mathrm{~g} / \mathrm{cm}^{3}$ to $1.06 \mathrm{~g} / \mathrm{cm}^{3}$. Milk sample with only sugar addiction had the highest specific gravity while the plain milk had the lowest. The values were comparable to that of soy milk $\left(1.03 \mathrm{~g} / \mathrm{cm}^{3}\right)$ and higher than $0.98 \mathrm{~g} / \mathrm{cm}^{3}$ for cow milk by $[2,30]$. The new York Department of Agriculture fixed the range of acceptable specific gravity in milk ranging between $1.03-1.034$ [31]. The plain cashew nut milk met this specification while the milk samples containing sugar and vanilla flavour had specific gravity above the recommended range.

There was a significant $(\mathrm{p}>0.05)$ difference in the $\mathrm{pH}$ of the cashew nut milk with values ranging from $5.60-6.50$. Plain cashew nut milk had the lowest $\mathrm{pH}$ while milk sample containing both sugar and vanilla flavour the highest. This study proved that cashew nut milk has an acidic $\mathrm{pH}$ and this is an indication of high susceptibility at ambient temperatures. Hence, the need to stabilize them through pasteurization and storage at appropriate cold temperatures are requisite. The acidic level recorded in this study suggestion that the produced cashew nut milk will be better consumed immediately in fresh state and as well suitable for patients with ulcer. The addition of sugar and vanilla flavour brought about a reduction in the $\mathrm{pH}$ of the milk products. The $\mathrm{pH}$ of the plain cashew nut milk is slightly lower than that of soy milk and cow milk with the values of 6.7 and 6.70 , respectively as reported by Hajirostamloo [32]. It was also comparable to the $\mathrm{pH}$ of melon seed milk (6.25) reported by Nnam [33].

The viscosity of the milk products ranged from 2.18 $2.80 \mathrm{Cp}$. The plain cashew nut milk had the highest viscosity while that containing only vanilla flavour had the lowest. However, there was no significant $(p<0.05)$ difference in the viscosity values of the cashew nut milk products. The viscosity values are lower compared to that of groundnut milk extract with the values that ranged from of 7.45 to $7.52 \mathrm{Cp}$ [34]. The viscosity depends on the amount of water used during the extraction process and it is an essential attribute for beverages. It is important in determining the rate of creaming of the milk, mass and heat transfer [34].

Total sugar content of the cashew nut milk products ranged from $3-14 \%$. The plain milk sample had the lowest sugar content while cashew milk containing only sugar had the highest. Total sugar content of the plain cashew nut milk is lower than that of tiger nut milk $(5.10 \%)$ and close to that of coconut milk (3.10\%) reported by Akusu and Emelike [5]. The highest sugar value observed in sample $\mathrm{D}$ is expected due to the addition of sugar to the milk.

Table 3. Physicochemical Properties of Cashew Nut Milk.

\begin{tabular}{|c|c|c|c|c|c|}
\hline Sample & T. T. A (\%) & Specific gravity $\left(\mathrm{g} / \mathrm{cm}^{3}\right)$ & $\mathbf{P h}$ & Viscosity & Sugar $\left({ }^{\circ}\right.$ brix $)$ \\
\hline A & $0.04 \pm 0.00^{\mathrm{a}}$ & $1.03 \pm 0.03^{\mathrm{a}}$ & $6.50 \pm 0.00^{\mathrm{a}}$ & $2.80 \pm 0.11^{\mathrm{a}}$ & $3.00^{\mathrm{d}}$ \\
\hline B & $0.12 \pm 0.00^{\mathrm{b}}$ & $1.05 \pm 0.01^{\mathrm{a}}$ & $5.90 \pm 0.00^{\mathrm{b}}$ & $2.33 \pm 0.09^{\mathrm{b}}$ & $12.00^{\mathrm{b}}$ \\
\hline $\mathrm{C}$ & $0.10 \pm 0.00^{\mathrm{c}}$ & $1.04 \pm 0.03^{\mathrm{a}}$ & $5.80 \pm 0.00^{\mathrm{c}}$ & $2.18 \pm 0.00^{\mathrm{b}}$ & $4.00^{c}$ \\
\hline $\mathrm{D}$ & $0.07 \pm 0.00^{\mathrm{d}}$ & $1.06 \pm 0.03^{\mathrm{a}}$ & $5.60 \pm 0.00^{\mathrm{d}}$ & $2.20 \pm 0.02^{\mathrm{b}}$ & $14.00^{\mathrm{a}}$ \\
\hline LSD & 0.00 & 0.09 & 0.00 & 0.26 & 0.04 \\
\hline
\end{tabular}

Key:

$\mathrm{A}=$ Plain cashew nut milk

$\mathrm{B}=$ Cashew nut milk containing sugar and vanilla flavor

$\mathrm{C}=$ Cashew nut milk containing only vanilla

$\mathrm{D}=$ Cashew nut milk containing only sugar.

a, b, c, d Mean values along the same column with similar superscript are not significantly different $(\mathrm{p}<0.05)$. Values represent means \pm standard deviation of duplicate determinations. 


\subsection{Sensory Characteristics of Cashew Nut Milk Samples}

The cashew nut milk containing sugar and vanilla flavour as well as the plain sample were evaluated for sensory characteristics and the result presented in Table 4. Colour and appearance of the cashew nut milk ranged from $2.80-3.70$ and $3.15-3.65$, respectively. The taste of the milk samples ranged from 1.80 - 4.15, mouth feel 2.10 - 3.95, flavour 2.20 3.80 , thickness $2.10-3.60$ and overall acceptability $2.45-4.05$. Cashew nut milk beverage containing only sugar was rated most preferred for all sensory parameters and this was significantly $(\mathrm{p}>0.05)$ different from all other milk samples. The addition of sugar and vanilla flavour was able to increase the sensory acceptability of the cashew nut milk samples. This is in agreement with Sutikno and Marniza [35] who reported increased sensory acceptability of fermented turi milk as concentration of sugar increased. Tranggono et al. [36] stated that the purpose of adding sugar and sweeteners to foods and drinks were to improve their taste, flavour, aroma and consumer preference. The increase in the overall acceptability of cashew nut milk is caused by the fact that sugar can improve the taste and flavour of foods. This is an indication that the cashew nut milk is better flavoured with sweeteners such as sugar and vanilla for consumers' acceptability. Meanwhile, health conscious consumers may choose cashew nut milk without sweeteners nor flavour for its chemical and mineral benefits.

Table 4. Mean Sensory Scores of cashew kernel milk Beverages.

\begin{tabular}{|c|c|c|c|c|c|c|c|}
\hline Samples & Colour & Appearance & Taste & Mouth feel & Flavour & Thickness & Overall Acceptability \\
\hline A & $2.80^{\mathrm{bc}}$ & $3.15^{\mathrm{b}}$ & $1.80^{\mathrm{c}}$ & $2.10^{\mathrm{c}}$ & $2.20^{\mathrm{c}}$ & $2.20^{\mathrm{c}}$ & $2.45^{\mathrm{c}}$ \\
\hline B & $3.10^{\mathrm{b}}$ & $2.70^{\mathrm{c}}$ & $3.95^{\mathrm{a}}$ & $2.25^{\mathrm{c}}$ & $4.15^{\mathrm{a}}$ & $2.10^{\mathrm{c}}$ & $3.90^{\mathrm{a}}$ \\
\hline $\mathrm{C}$ & $2.65^{\mathrm{c}}$ & $3.00^{\mathrm{bc}}$ & $2.40^{\mathrm{b}}$ & $2.90^{\mathrm{b}}$ & $3.25^{\mathrm{b}}$ & $2.70^{\mathrm{b}}$ & $2.80^{\mathrm{b}}$ \\
\hline $\mathrm{D}$ & $3.70^{\mathrm{a}}$ & $3.65^{\mathrm{a}}$ & $4.15^{\mathrm{a}}$ & $3.95^{\mathrm{a}}$ & $3.80^{\mathrm{a}}$ & $3.60^{\mathrm{a}}$ & $4.05^{\mathrm{a}}$ \\
\hline LSD & 0.44 & 0.44 & 0.48 & 0.55 & 0.44 & 0.45 & 0.37 \\
\hline
\end{tabular}

a, b, c, d Mean values along the same column with similar superscript are not significantly different $(\mathrm{p}<0.05)$. Values represent means \pm standard deviation of duplicate determinations.

\section{Conclusion}

This study proves that cashew nut milk can be utilise as substitute to alleviate the cost of diary milk and for its high nutrients contents. The addition of sugar and vanilla flavour in the milk significantly $(\mathrm{p}>0.05)$ reduced the $\mathrm{pH}$ and viscosity of the milk with a corresponding increase in the titratable acidity making it less acidic for ulcer patients. The addition of sweeteners and flavours further enhances the suitability and acceptability of the produced milk drink. It is therefore suggested that the milk from cashew nut be encouraged to stabilize the cost of diary milk; most especially in rural communities where accessibility and cost of animal milk are major challenges to the people.

\section{References}

[1] Saleem-ur-Rehman M., Ahmad M., Yameed A., Almas K. and Muntaha S. (2004). Sensory and nutritional evaluation of coconut-natural milk blend. Pakistan Journal of Life Social Science, 2 (2), 104-108.

[2] Ajala L., Ologunde M. O and Adetuyi F. O. (2013). Physicochemical and sensory qualities of spiced soy corn milk. African Journal of Biotechnology, 12 (7), 2262-2265.

[3] Adedokun I. I., Okorie S. U., Batu B. (2014). Evaluation of proximate, fibre qualities and consumer acceptability of bambaranut-tigernut-coconut milk beverage blends. International Journal of Nutrition and Food Sciences, 3 (5), 30-437. Doi: 10.11648/j.ijnfs.20140305.20.

[4] Mensah-Brown H., Afoakwa E. O., and Wadie W. B. (2014). Optimization of the production of a chocolate-flavoured, soy-peanut beverage with acceptable chemical and physicochemical properties using a three-component constrained extreme lattice mixture design. Food Science and Quality Management, 23, 46-54.

[5] Akusu O. M. and Emelike N. J. T. (2018). Physicochemical and organoleptic properties of flavored vegetable milk drinks made from tiger nuts (Cyperus esculentus) and Coconuts (Cocos nucifera) milk blends. International Journal of Food Science and Nutrition, 3 (2), 05-11.

[6] Anderson J. W., Johnstone B. M. and Cook-Newell M. E. (1995). Meta-analysis of the effects of soy protein intake on serum lipids. New England Journal of Medicine, 333 (5), 276-282.

[7] Sethi S., Tyagi S. K. and Rahul K. A. (2016). Plant-based milk alternatives, an emerging segment of functional beverages: a review. Journal of Food Science and Technology, 53 (9), 3408-3423.

[8] Muniz C. R., Borges M. D. F. and Freire F. D. C. O. (2006). Tropical and Subtropical Fruit Fermented Beverages. In: Microbial, Biotechnology and Horticulture, Ray R. C and Ward O. P. (editors). Science Publishers, Vol 2. Enfield, NH., USA.

[9] FAO (2000). Cashew production in Africa, 1961-2000. Food and Agriculture Organization of the United Nations. Production Database, http: //apps.fao.org/.

[10] UNIDO (2011). Tanzania Cashew Value Chain: Diagnosite. United Nations Industrial Development Organization (UNIDO) Vienna, Austria p. 66.

[11] Emelike N. J. T., Barber L. I. and Ebere C. O. (2015). Proximate mineral and functional properties of defatted and undefatted cashew (Anacardium occidentale) kernel flour. European Journal of Food Science and Technology, 3 (4), 11-19. 
[12] Emelike N. J. T. and Barber L. I. (2018). Effect of cashew kernel and soya bean oils on blood serum cholesterol and triglyceride of albino rats (Rattus rattus). Asian Food Science Journal, 1 (2), 1-6.

[13] Onyeike E. N and Ikuru P. R. (1998). Preliminary investigation of the proximate composition of heat processed cashew nut seed flours. Plant Foods for Human Nutrition, 48 (2), 85-93.

[14] Aremu M. O, Olonisakin A, Bako D. A and Madu P. C (2006). Compositional studies and physicochemical characteristics of cashew nut (Anacardium occidentale) flour. Pakistan Journal of Nutrition, 5 (4), 328-333.

[15] Ogunwolu S. O, Henshaw F. O, Mock H. P, Santos A and Awonorin S. O (2009). Functional properties of protein concentrates and isolates produced from cashew (Anacardium occidentale L.) nut. Food Chemistry, 115, 852-858.

[16] Emelike N. J. T and Ebere C. O (2015). Influence of processing methods on the tannin content and quality characteristics of cashew by-products. Agriculture and Food Sciences Research, 2 (2), 56-61.

[17] Afolabi I. S, Nwachukwu I. C, Ezeoke C. S, Woke R. C, Adegbite O. A, Olawole T. D and Martins O. C (2018). Production of a new plant-based milk from adenanthera pavonina seed and evaluation of its nutritional and health benefits. Frontiers in Nutrition, 5 (9), 1-13. Doi: 10. 3389/fnut. 2018. 00009.

[18] Jane C. O and Chizoba N (2009). Development and Evaluation of Vegetable Milk from Treculia africana (Decne) Seeds. Pakistan Journal of Nutrition, 8 (3), 233-238. Doi: 10.3923/pjn. 2009.233.238.

[19] Makinde F. M and Adebile T. V (2018). Influence of processing treatments on quality of vegetable milk from almond (Terminalia catappa) kernels. Acta Scientific Nutritional Health, 2 (6), 37-42.

[20] AOAC (2012). Official Methods of Analysis. (19 ${ }^{\text {th }}$ ed, $)$ Association of Official Analytical Chemists, Galthersburg, M. D. USA.

[21] Iwe M. O. (2002). Handbook of Sensory Methods and Analysis. Rojoint Community Services Ltd, Enugu, Nigeria.

[22] Rehman S., Hussain S., Nawaz H., Ahmad M., Huma N. and Virk W. A. (2007). Preparation and quality evaluation of Lathyrussativus L. Bovine milk blend, Pakistan Journal of Nutrition, 6, 134-137.

[23] Alyaquobi S., Abdullah A., Samudi M., Abdullah N., Addai Z. R and Musa K. H. (2015). Study of antioxidant activity and physicochemical properties of coconut milk (Patisantan) in Malaysia. Journal of Chemical and Pharmaceutical Research, 7 (4), 967-973.
[24] Passmore R. and Eastwood W. A. (1986). Human Nutrition and Dietetics, $8^{\text {th }}$ Edition, New York, England.

[25] Emmanuel N., Onadipe O., Amadou T. D., Hanna R., Kirscht H., Maziya-Dixon B., Araki S., MbairanodjiA. and Ngue-Bissa T. (2014). Cassava processing among small-holder farmers in Cameroon: Opportunities and challenges. International Journal of Agricultural Policy and Research, 2 (4), 113-124.

[26] Awonorin S. O. and Udeozor L. O. (2014). Chemical properties of tiger nut-soy milk extract. Journal of Environmental Science, Toxicology and Food Technology, 8 (3), 87-98.

[27] Manzoor M. F. and Ahmed N. (2017). Extraction and utilization of Manihot esculenta crantz and Trapanatans starch as a stabilizer in soy milk based ice cream preparation, Agricultural Research and Technology, 8 (2), 001-005.

[28] Alozie Y. E and Udofia U. S. (2015). Nutritional and sensory properties of almond (Prunusamygdalu var. Dulcis) seed milk. World Journal of Dairy and Food Sciences, 10 (2), 117-121.

[29] Chima O. A., Abuajah C. I. and Utuk R. A. (2013). Tiger nut milk: a nutritious under-utilized food ingredient. Food Biology, $2(2), 14-17$.

[30] Ukwo S. P. (2015). Physicochemical profile and sensory attributes of plain yoghurt from cow and soy milk blends. Nigerian Journal of Agriculture, Food and Environment, 11 (2), 20-23.

[31] Pearson D. (1981). The Chemical Analysis of Food. Churchill Livingstone, Edinburgh, 504-530.

[32] Hajirostamloo B. (2009). Comparison of nutritional and chemical parameters of soymilk and cow milk. International Journal of Nutrition and Food Engineering, 3 (9), 455-457.

[33] Nnam N. M. (2003). Nutrient composition and acceptability of vegetable milk made from oil seeds, Journal of Home Economics Resource, 5, 57-61.

[34] Adesola A. O., Olasunkanmi G. S. and Kehinde T. A. (2013). Effects of some processing factors on the characteristics of stored groundnut milk extract. African Journal of Food Science, 7 (6), 134-142.

[35] Sutikno S. R and Marniza (2013). Effects of sugar type and concentration on the characteristics of fermented turi (Sesbania grandiflora (L.) Poir) milk. Emir. Journal of Food and Agriculture, 25 (8), 576-584. Doi: 10.9755/ejfa.v25i8.15062.

[36] Tranggono S., Suparmo M. S. U., Agnes S., Sudarmadji K., Rahayu S. N and dan M. Astuti (1990). Bahan Pangan (Food Additives). PAU-Pangandan Gizi UGM. Yogyakarta. 